\title{
Consumerism, Status Quo, and Virtual Reality through Food Photos Uploading on Instagra
}

\author{
Alfitri, Farisha Sestri Musdalifah
}

\begin{abstract}
The rapid development of information technology and the proliferation of restaurants and cafes in urban areas make eating activities no longer a primary need. This study examines the phenomenon of uploading food photos on Instagram. Nowadays, when eating out, people tend to take food photos before consuming it. This phenomenon is something that generally happens. The food photo is uploaded to social media, mostly on Instagram. The uploader of food photos on Instagram is known as Instagram Foodies. These symptoms continue to be made by consuming food and eating out not for the purpose of primary needs, but rather on symbolic things. This phenomenon will be examined using Jean Baudrillard's theory about consumer society, who consumes signs to fulfil the desire for selfexistence. This study used a qualitative method by interviewing four foodies who were well known in following the latest trends of foods and places in Jakarta city and taking food photos before consuming it. The result of this study shows that foodies will continue to consume and keep up with the latest trends in food so that it can be uploaded to Instagram as content. This activity is done to maintain their status quo as the foodies on Instagram. The foodies believe that food consumption and uploading food photos on Instagram are done with a desire to show self-existence on Instagram as its virtual reality. The virtual reality of the foodies is the symbol as 'the foodies' on Instagram itself.
\end{abstract}

Keywords: Food Consumerism; Food Photos; Consumer Society; Status Quo; Instagram; Virtual Reality

\section{INTRODUCTION}

The growth of information and communication technology is changing almost all activities in human lives. The presence of the internet gave birth to various new media, which made it easier for people to access information. In Indonesia, the highest number of internet users is from Java Island. Meanwhile, cities with the most internet use in Indonesia is DKI Jakarta (Kominfo, 2013). Based on a survey from APJII (Indonesian Internet Service Providers Association) in 2017, penetration of internet use in Indonesia shows that $87.13 \%$ of people access the internet to use social media (APJII, 2017).

One activity that shifts with social media presence is eating activity. Eating is the most basic necessity for people to survive (Widyosiswoyo, 1991). Based on research from Hartman Group in 2012, social media changes the human habit, one of them is the habit when eating. Consumers prefer to search for information about the latest food trends and restaurants through the images displayed on social media. Hartman Group ("Digital Food Life 2014: How technology shapes the way consumers eat," 2014) even concluded that social media and food are a perfect match.

Revised Manuscript Received on April 19, 2019.

Dr. Alfitri, Department of Sociology, Faculty of Social and Political Science, Sriwijaya University, Palembang, Indonesia.

Farisha Sestri Musdalifah, Lecturer, Faculty of Social and Political Science, Sriwijaya University, Palembang, Indonesia.
Thirty-two percent of consumers use social media when they are eating or drinking, and this proportion even rises to 47 percent in millennial society. This phenomenon demonstrates that consumers like to share their eating experiences on social media by uploading food pictures or activities while eating.

The proximity between social media and eating activities is in line with the outcomes of Fitria's study on the occurrence of makan cantik (eating beautifully) in the Senopati region, Jakarta City. When makan cantik performed, people tend to display their eating activities on social media to create an image of the upper class (Fitria, 2015). Food pictures uploaded on social media have appealing and appetizing displays. This statement is also consistent with the outcomes of Raditya's research that those who ate foods with an aesthetic and appealing appearance tended to be considered classier (Raditya, 2014). In this situation, social media is a place to show these eating activities, so there is a change in the meaning of eating itself.

One of the most popular social media for photo sharing is Instagram. Based on data from WeAreSocial, Instagram is in fourth place as the most used social media in Indonesia, while YouTube, WhatsApp, and Facebook occupy the first to third places (WeAreSocial, 2019). Compared to these three, Instagram is a social media that has specific characteristics for sharing pictures and videos of its users' daily activities. The features provided by Instagram allow users to take and edit their photos before uploading them. As a social media that focuses on features for photo sharing, Instagram is the perfect place to display activities and lifestyles for its users, including eating out activities.

Now, the phenomenon of uploading food photos to social media, particularly Instagram, is not unusual. Food photos that have an attractive and appealing appearance make food can be categorized as Insta-worthy or Instagramable (worth uploading to Instagram). Various Instagram-themed food accounts are increasing, especially in Jakarta. For example, the @jktfooddestination's Instagram account currently has 840.000 followers, the @jktfoodbang's account has 669.000 followers, and @anakjajan's has 324.000 followers. The number of followers on that food-themed account indicates a high interest in attractive and appealing trending foods. This case makes the ritual of taking food photos before consuming it is not something that unfamiliar among urban societies. Also, the term foodies also arise, namely people who have an interest in finding out and following the latest trends of tasty and exciting foods (Johnston \& Baumann,

Published By: 
2015). More simply, Lisa Heldke describe foodies as a food adventurer (Heldke, 2003). It is not uncommon for foodies to use their personal Instagram accounts to display the foods that they eat.

The phenomenon of society that loves uploading food pictures on social media like Instagram shifts the meaning of eating itself. Eating is indeed a basic need for human beings to survive. The type of food with a varied appearance backed by the fast growth of technology making eating activities no longer just to fulfil hunger, but the activities to represent certain classes. Instagram is a perfect place for displaying food consumption. The emergence of the term foodies has become a distinctive symbol for Instagram users as people who follow the latest food trends in urban areas, in this case, Jakarta, as the capital city of Indonesia.

The problem is, to continue to perpetuate the symbol as the foodies, then the foodies must continue to consume food by eating out and keeping up-to-date with the latest eating places as a photo content so that it can be uploaded to Instagram.

Baudrillard, a philosopher from France, mentioned the phenomenon of consumption to follow the trend. In his book entitled The Consumer Society, Baudrillard describes consumption is not just an activity to fulfill needs, but because it gives meaning to an object as part of a system in the form of signs or codes, language, and morals. According to Baudrillard, today's society is no longer dominated by production but is controlled by consumption (Ritzer \& Goodman, 2014). Consumption carried out by individuals, in this case, food consumption is not only to fulfill their primary needs but also as a status marker.

Based on the phenomenon described above, this study will examine how foodies maintain their status quo as 'foodies' on Instagram through food consumption.

\section{LITERATURE REVIEW}

\subsection{Jean Baudrillard's Thought of Consumption}

In Marxist thought, an object has two values, namely, use value and exchange value. Use value is a function contained in the object, while exchange value is the price of an object for the trade (Lee, 2015). Jean Baudrillard criticizes Marx's conception of these two values because they are considered irrelevant. In Baudrillard conception, an object has two other values, namely symbol values and sign values (Baudrillard, 1981). A symbol value is when an object symbolizes something, such as a ring that symbolizes the relationship status. Meanwhile, the sign value is when the object is related to other signs. For example, a certain brand of hand watch signifies a person's socio-economic status. When an object has become a sign, the object becomes more valuable and desired by many people. The sign is a production machine. For example, buying drinks at Starbucks is more valuable than at a convenience store because of the Starbucks logo on the cup. Wearing Nike's sneakers is more valuable than non-branded sneakers simply because there is a Nike logo on it.

\subsection{Eating Out, Food, Instagram, and Foodies}

Eating is one of the primary needs of human life. In urban communities, eating out is very common. The phenomenon of eating out is not just to fulfill the need for food, but as an activity to preserve its class culture (Ansori, 2009). Ansori's study of the middle class in Indonesia shows that the culture of eating out in a café is one of the efforts made by urban societies in Indonesia to differentiate their class.

Kittler and Sucher mention that you are what you eat, so that food can be a lifestyle for someone to express their identity (Kittler \& Sucher, 2008). The shifting meaning of eating makes eating activities become fashionable, something that is trendy and must always be renewed (Fox, 2014). When new types of food appear that look unique, people will consume those new things. The ambience of the eating place and the appearance of the food served is as important as the food itself. This is reflected in Raditya's research on 2014 that those who eat foods with an aesthetic and attractive appearance tend to be considered classier (Raditya, 2014). Therefore, eating out is not only an activity to satisfy hunger, but there are certain lifestyles such as following trends and showing consumer's socio-economic class. It can be said that food plays a symbolic role as a communication practice that we can create, manage, and share its meaning with others (Stajcic, 2013). In connection with Baudrillard thinking as described previously, food is no longer related to use value (fulfillment of primary needs), but as a fashion.

The presence of social media like Instagram makes it easier for users to find and share experiences from food and drinks consumed in real-time. Foodies, or food adventurers also often to upload the food that they consume to their Instagram account.

\section{METHODOLOGY/MATERIALS}

This research has used a qualitative approach. Based on Creswell, qualitative research is a technique that investigated and clarified the significance of people or groups deemed to have come from the phenomenon/problem of society or humanity (Creswell, 2010). A qualitative approach is identified by social construction over truth and cultural significance, in which authenticity is the key to this approach. This approach is considered useful in this study because a qualitative approach has attempted to test subjective reality from the experience of people who like eating out and taking photos of their food before uploading them to Instagram. The data was collected by depth interview and observation to four informants, who are Zomato's top foodies. Zomato is an application for a restaurant directory and review with the largest number of users in Indonesia. The top foodies also often uploading food photos on their Instagram account. Besides that, the observation was carried out on the four foodies by following their activities when eating out. Observations were also made by observing the foodies Instagram account to see food photos that have been uploaded. The data were analyzed thematically by categorizing through open coding, axial coding, and selective coding. 


\section{RESULTS AND FINDINGS}

The informants in this research are four foodies who were the top foodies on the website of Zomato Indonesia. Of the four foodies, two are males (initials YIS and SM) and two are females (initials IK and UR). These four foodies are active users of Instagram and regularly upload food photos on their Instagram accounts. The following table is a description of four informants:

Table1. Informant's General Description

\begin{tabular}{|c|c|c|c|c|}
\hline $\begin{array}{l}\text { Descript } \\
\text { ion }\end{array}$ & YIS & SM & IK & UR \\
\hline $\begin{array}{l}\quad \text { Age, } \\
\text { Marital } \\
\text { Status }\end{array}$ & $\begin{array}{l}30 \text { years } \\
\text { old, } \\
\text { single }\end{array}$ & $\begin{array}{l}28 \text { years } \\
\text { old, single }\end{array}$ & $\begin{array}{l}41 \text { years } \\
\text { old, } \\
\text { married }\end{array}$ & $\begin{array}{l}48 \text { years } \\
\text { old, } \\
\text { married }\end{array}$ \\
\hline $\begin{array}{l}\text { Occupat } \\
\text { ion }\end{array}$ & Police & $\begin{array}{l}\text { Bank's } \\
\text { Legal } \\
\text { Corporate }\end{array}$ & $\begin{array}{l}\text { Magazine } \\
\text { editor }\end{array}$ & $\begin{array}{l}\text { Vice } \\
\text { Secretary }\end{array}$ \\
\hline $\begin{array}{l}\text { Educati } \\
\text { on } \\
\end{array}$ & Bachelor & Bachelor & Bachelor & Diploma \\
\hline $\begin{array}{l}\text { Living } \\
\text { with }\end{array}$ & Parents & Parents & Husband & Husband \\
\hline Domicile & $\begin{array}{l}\text { Depok, } \\
\text { West } \\
\text { Java }\end{array}$ & $\begin{array}{l}\text { West } \\
\text { Jakarta }\end{array}$ & $\begin{array}{l}\text { Depok, } \\
\text { West } \\
\text { Java }\end{array}$ & $\begin{array}{l}\text { East } \\
\text { Jakarta }\end{array}$ \\
\hline
\end{tabular}

Source: in-depth interview

\subsection{Eating Out as a Lifestyle}

Warde and Martens state that the common reason for eating out is to try something different from eating activities that are done daily, such as a break from cooking, wanting to be served, relaxing, socializing, celebrate something, or want to eat certain foods (Warde \& Martens, 2003). Based on in-depth interviews and observations of the four informants as the foodies, it was seen that each of them had a lifestyle pattern of eating out and uploading food photos on Instagram in different ways. For them, eating out is interpreted as a lifestyle, not just to fulfill hunger. The four informants stated that their biggest expenditure was to buy foods. Eating out has become a daily lifestyle for them.

Even the choice of places to eat is not arbitrary. One informant mentioned that he was more comfortable eating in restaurants, cafes, of coffee shops with reasons for being cleaner and healthier. This shows that eating out is not just eating, but it has its own prestige. Research results also indicate that informants have chosen food and restaurants linked to their social class. For instance, the Plataran restaurant in Menteng, Central Jakarta as one of the informants ' choice to eat is a restaurant that can be classified as a classy restaurant. Besides its place in the elite area, the cost of the menus provided is also not inexpensive. Description of informants' eating out activities are described in the following table:
Table 2. Informant's Eating Out Activities

\begin{tabular}{|c|c|c|c|c|}
\hline $\begin{array}{l}\text { Descript } \\
\text { ion }\end{array}$ & YIS & SM & IK & UR \\
\hline $\begin{array}{l}\text { Eating } \\
\text { out/day }\end{array}$ & $\begin{array}{l}\geq 2 \\
\text { (average) }\end{array}$ & $\begin{array}{l}\geq 2 \\
\text { (average) }\end{array}$ & $\begin{array}{l}\geq 2 \\
\text { (average) }\end{array}$ & $\geq 3$ (often) \\
\hline Meaning & Lifestyle & $\begin{array}{l}\text { Primary } \\
\text { needs, } \\
\text { jobs } \\
\text { (endorser) }\end{array}$ & Lifestyle & $\begin{array}{l}\text { Primary } \\
\text { needs }\end{array}$ \\
\hline $\begin{array}{l}\text { Kind of } \\
\text { place }\end{array}$ & $\begin{array}{l}\text { Coffee } \\
\text { Shop }\end{array}$ & $\begin{array}{l}\text { Indonesian } \\
\text { Restaurant }\end{array}$ & $\begin{array}{l}\text { Coffee } \\
\text { Shop }\end{array}$ & $\begin{array}{l}\text { Indonesian } \\
\text { Restaurant }\end{array}$ \\
\hline $\begin{array}{l}\text { Eating } \\
\text { expenses } \\
\text { /week }\end{array}$ & $\begin{array}{l} \pm \$ 71 \\
\text { (low) }\end{array}$ & $\begin{array}{l} \pm \$ 50 \\
\text { (low) }\end{array}$ & $\begin{array}{l} \pm \$ 107 \\
\text { (average) }\end{array}$ & $\begin{array}{l} \pm \$ 250 \\
\text { (high) }\end{array}$ \\
\hline Trend & Follower & Follower & $\begin{array}{l}\text { Up to } \\
\text { date }\end{array}$ & Up to date \\
\hline $\begin{array}{l}\text { Choices } \\
\text { of places }\end{array}$ & Variative & Comfort & Variative & Variative \\
\hline Purpose & Curious & Needs & Curious & Curious \\
\hline
\end{tabular}

Source: in-depth interview

The results of in-depth interviews show that all informants are eating out every day with different frequencies. YIS, SM, and IK can be categorized as average ( 2 times/day) for the frequency of eating out. Meanwhile, UR is categorized as often (more than three times/day) for frequency of eating out. The meaning of eating out activities is different for each informant. Some interpret it as a lifestyle, and some gives meaning to it as a primary need. Even one of four informants, SM, interprets eating as revenue (endorsement). The average amount of money spent by each informant for eating out are varied every week. SM is an informant with the lowest weekly food expenses among other informants, which is around \$50/ week. This amount is because SM often consumes the food that was sent to him for endorsement purposes. Meanwhile, the informants with the highest food expenses were UR, with an average food expense around $\$ 250 /$ week. This amount is related to the meaning of eating out for UR as a daily necessity.

There are two types of informants on following the trends of eating places in Jakarta, as followers and as up-to-date people. YIS and SM are followers because they do not really want to follow the current food trends. Meanwhile, UR and IK are categorized as up-to-date because they are always looking for and want to try the latest food trends. The choice of eating out places of each informant is also different. For YIS, UR, and IK, they are always looking for the newest places to eat because they do not want to eat in the same place. Meanwhile, SM choosing an eating place that he feels comfortable because he is not really a follower of the latest food trends. 


\subsection{Instagram as a Place to Upload Food Photos}

The presence of social media and the emergence of multiple advanced techniques have led the camera to capture almost every moment, including activities while eating out. Every smartphone today is also fitted with a camera with excellent image quality. Therefore, taking pictures of food before eating is not unusual. This phenomenon was performed in sharing their eating experiences by the four informants in this research. Taking food pictures before eating is an obligation for the four informants when eating out. Not only do these foodies take food pictures, but they also often take pictures of the interior and the environment of the food locations that they visit.

The tools that are used by foodies in taking food photos also vary. For YIS and SM, they both use a mirrorless digital camera when taking food photos. Meanwhile, UR and IK use their smartphone.

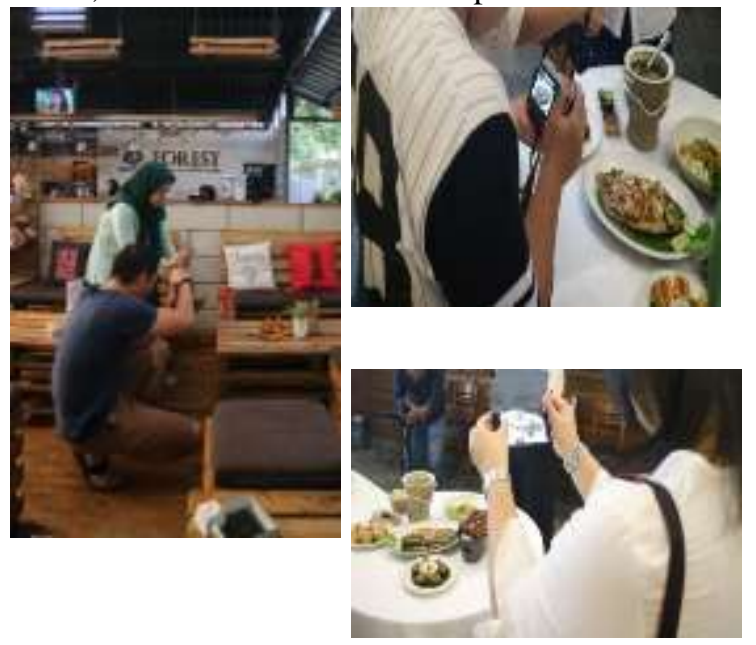

Figure 1. Informants taking photos of their food before eating

Figure 1 above shows how informants took food photos before consuming it. Food photos taken are not directly uploaded to Instagram. Instead, the pictures are stored to be uploaded later. YIS, one of the informants said that food photos that had been taken were stored to be uploaded to adjust the food theme on his Instagram account. This figure below shows the examples of food photos that YIS's uploaded on his account.

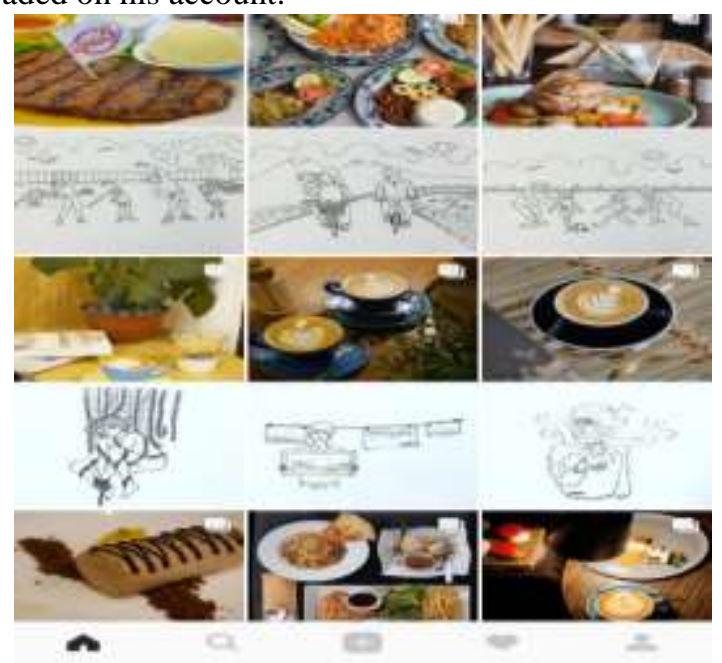

Figure 2. YIS's Instagram Feed
Just like YIS, IK did not directly upload food photos he took on Instagram. According to IK through a thorough interview, uploading photos to Instagram requires the mood and exciting captions, so IK tends to keep food photos that she took and wait for the right time to upload. In one week, IK said that she could upload two to three photos on her Instagram account. Food photos that IK choose to upload based on the good impression obtained after consuming food or drinks and how attractive the foods look. This figure below shows the food photos that IK's uploaded.

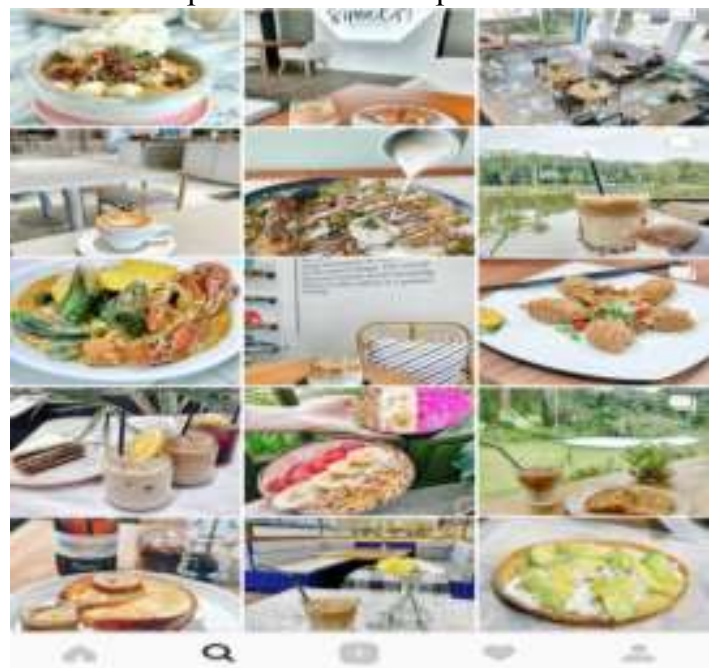

Figure 3. IK's Instagram Feed

Unlike YIS and IK, UR took the late start of uploading food photos on Instagram. UR created her Instagram account in the middle of 2015. Before that, UR claimed to only have Facebook, Zomato, and Pergikuliner (restaurant directory application) as her social media to uploading food photos. Since that, she has uploaded food photos regularly on her Instagram account. This figure below shows the food photos that UR's uploaded.

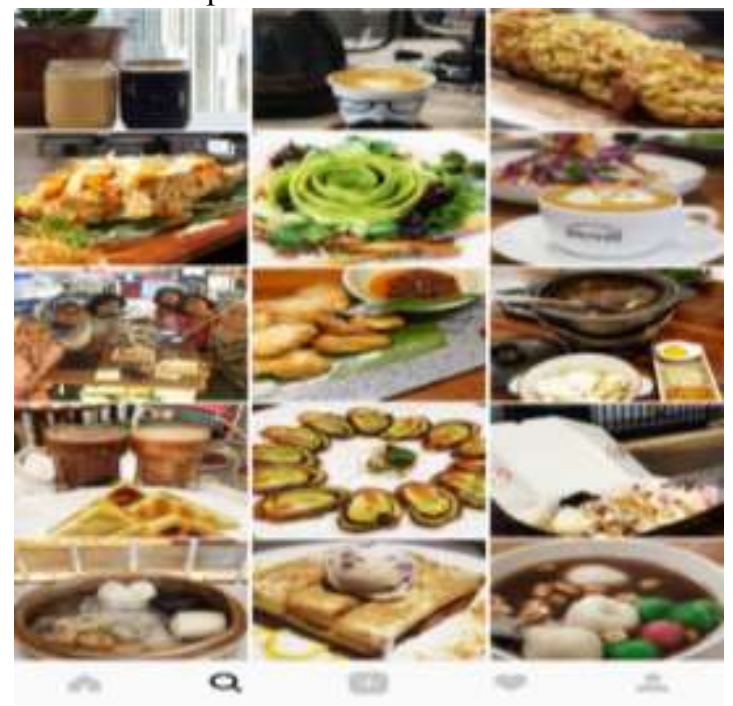

Figure 3. UR's Instagram Feed

Finally, for SM, Instagram has been one of the sources of his income since he became a food endorser. Before becoming an endorser, SM claimed that he rarely uploaded

Published By: Blue Eyes Intelligence Engineering \& Sciences Publication

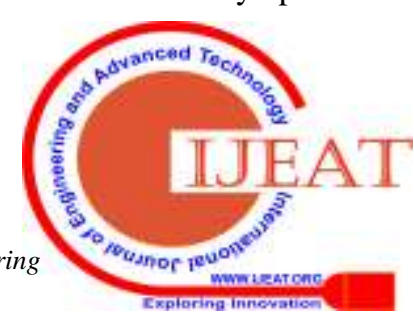


food photos on his Instagram account. He only likes to write reviews of places to eat on his blog and restaurant directory application, such as Zomato, Pergikuliner, and Nibble (restaurant directory application). Since he began to upload food photos on Instagram, his account began to gain more and more followers. SM used a mirrorless camera to take food photos. The quality of the pictures taken is getting greater compared when he still uses a smartphone for taking pictures. Some food photos he uploaded made his Instagram profile become full of likes and gain new followers. He also often becomes an endorser to promote food or a place to eat. This figure below shows the examples of food photos that SM's uploaded on his account.

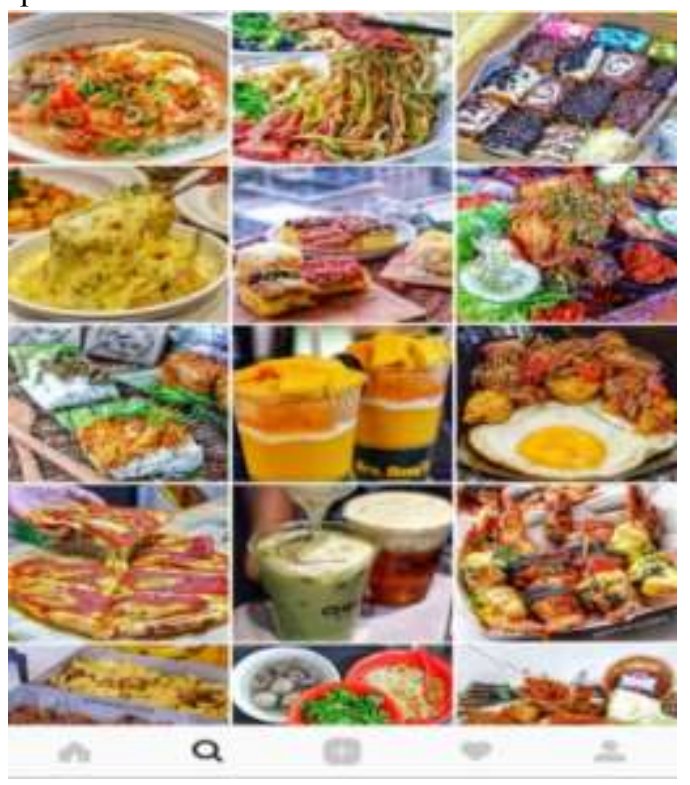

Figure 4. SM's Instagram Feed study, SM is the informant with the highest number of followers, which is 39.200 followers. The existence of SM in the culinary world in Jakarta City is well known for its number of followers that are not small. In addition to uploading food photos of his personal consumption, SM often receives endorsement service to promote places to eat and menus offered. In one day, SM can upload one to three photos on his Instagram account, whether it is in the form of endorsement photos or his personal food photos. There is a consideration for SM to choose food photos that he took (other than photos for endorsement) to upload to Instagram, which is a photo that can arouse his appetite. In addition, SM also considers the photo with an attractive appearance.

\subsection{Discussion}

Eating out is not unusual for Indonesian urban communities. As mentioned previously in the literature review, Ansori said that the phenomenon of eating out is not just to fulfill the need for food, but as an activity to preserve its class culture (Ansori, 2009). Eating out is not unusual for Indonesian urban communities. As mentioned previously in the literature review, Ansori (Ansori 2009) said that the phenomenon of eating out is not just to fulfill the need for food, but as an activity to preserve its class culture. This activity becomes relevant when the informants say they interpret eating out as a lifestyle. In other words, eating out is not only an activity to satisfy hunger but also an activity
Among the four foodies who became informants in this

to hang out and look for the ambience. Meanwhile, there were also informants who visited places to meet their food needs. However, the selection of places to eating out is not arbitrary, because there are informants who prefer restaurants and coffee shops with reasons that are cleaner and healthier than eating in an ordinary place like fast food chain or canteen. This reason illustrates that eating out is not just to eat, but has its own prestige to distinguish social class.

In this phenomenon of food consumption, there is a logic of fashion that plays. As Baudrillard said, a logic of fashion happens when objects are always updated to continue to be consumed. The research findings show that informants are always looking for and want to try the latest eating place and up to date to follow the trends. In addition, uploading food photos by informants on Instagram also shows food and eating places that are trending. By visiting the latest eating places or eating current food trends and then uploading them to Instagram, informants want to show themselves differently because they follow the trend. When the latest types of food appear, there will be many people who consume these foods.

The practice of consuming the latest food trends is not immediately carried out simultaneously. There is an elite group as the first reference to eating it. Based on the results of the study, the elite group that became the trend reference is like UR and IK who were always looking for the latest places to eat for consumption and upload the pictures on their Instagram account. Meanwhile, YIS and SM tend to act as followers. In this case, food has become an object of consumption which is no longer seen based on exchange value and its function. The trend of food displayed on social media makes food now associated with social logic and the desire to be different from others. This happens when the informants who do eating out every day do not want to eat in the same eating place that they have visited. When the most recent eating places appear, the informants don't want to be left behind to keep up with trends. This keeps happening and will never end because the newest food trends will always appear. Meanwhile, the need to follow the trend if it satisfied will arise other needs.

However, what is really happening behind the phenomenon of uploading food photos on social media, in this case, Instagram? The phenomenon of taking and uploading food photos on Instagram indicates that there are simulations carried out by the uploader, namely lifestyle simulations. Ansori through his journal in 2009 explained that eating in cafes was an effort made by middle-class people in Jakarta to distinguish themselves from the lowerclass society. Middle-class people are those who imitate the lifestyle of the upper class who are able to eat in classy restaurants. To follow the high-end lifestyle, the middleclass people create cafes with a quite luxurious ambience with affordable food prices. In line with Ansori's writing, the phenomenon of consuming the trends and uploading them to Instagram shows the lifestyle simulation, that the ideal lifestyle for them is like the one that they upload on 
their Instagram account. This is also related to Jakarta City as Indonesia's capital city, where the primary needs are already abundant with the creation of multiple dining alternatives. The emergence of terms such as Instagrammable food or Instagrammable eating places is the example that today's eating places not only sell food taste but also sell places so that visitors can take photos that are considered appropriate to be uploaded to Instagram. The pattern of consumerism as describe by Baudrillard not only revolves around buying and consuming objects, but also shows them to people through social media.

All attempts taken to display Instagram's eating out lifestyle are driven by the desire. In accordance with Baudrillard's statement, that consumption is no longer related to its value, but the desire to be different from others (Baudrillard, 1981). Coming to a place to eat, order, consume, and pay is an ordinary thing that exists in humans to fulfill their primary needs. However, the choice of eating place to be visited is a desire that is different from other people.

The phenomenon of uploading food photos, the desire that uploaders (foodies) want to achieve is the existence of themselves as a foodie in cyberspace. All informants in this study are foodies who have many followers on Instagram. Based on research findings, the existence of foodies that upload food photos on Instagram is not only a matter of food consumption and lifestyle but also the existence in the virtual world. This study makes the discussion about the phenomenon is not just about food consumption, but has become a virtual reality. In the real world, foodies as the informants of this research are just the ordinary people who live their lives. But in cyberspace, in this case, Instagram, they are known as foodies. This shows that the virtual world has been brought along and slowly become the real world. To maintain the status quo as foodies, they continue to consume food and eating out to take the photo as content and upload it to Instagram.

\section{CONCLUSION}

Eating is one of the basic needs of human life. The presence of new media such as Instagram makes food consumption not only have use value to meet humans' primary needs. Like fashion, food also has a logic of fashion so that the latest food trends continue to emerge. Therefore, the food photos on social media not only represents food with its value, but also there is a sign value. Instagram makes its users able to display their daily lifestyle, in this case, the lifestyle of eating out. Those who always follow the food trend are called foodies. To maintain the status quo as foodies, they must continue to follow food trends and eat food by eating out. This activity will continue to happen to be their life cycle.

\section{REFERENCES}

1. Ansori, M. (2009). Consumerism and the emergence of a new middle class in globalizing Indonesia. Explorations a graduate student journal of Southeast Asian Studies, 9, 87-97.

2. APJII. (2017). Infografis Penetrasi dan Perilaku Pengguna Internet Indonesia 2017 (Infografis).
Retrieved 20-03-2019, from

APJII https://apjii.or.id/survei

3. Baudrillard, J. (1981). For a Critique of the Political Economy of the Sign. United States of America: Telos Press.

4. Creswell, J. W. (2010). Research Design, Pendekatan Kualitatif, Kuantitatif, dan Mixed, Edisi Ketiga. Yogyakarta: Pustaka Pelajar.

5. Digital Food Life 2014: How technology shapes the way consumers eat (Report). (2014). Retrieved 19-03-2019, from The Hartman Group https://www.hartmangroup.com/newsletters/2146136962/digital-food-life2014-how-technology-shapes-the-way-consumers-eat

6. Fitria, H. (2015). HIPERREALITAS DALAM SOCIAL MEDIA (STUDI KASUS: MAKAN CANTIK DI SENOPATI PADA MASYARAKAT PERKOTAAN). Informasi, 45(2). doi https://doi.org/10.21831/informasi.v45i2.7985

7. Fox, R. (2014). Food and Eating: An Anthropological Perspective. http://www.sirc.org/publik/foxfood.pdf

8. Heldke, L. (2003). Exotic Appetites: Ruminations of a Food Adventurer. New York: Routledge.

9. Johnston, J., \& Baumann, S. (2015). Foodies: Democracy and Distinction in the Gourmet Foodscape (Second ed.). New York: Rouledge.

10. Kittler, P., \& Sucher, K. P. (2008). Food and Culture, 5th Edition. United States of America: Thomson Wadsworth.

11. Kominfo. (2013). Kominfo : Pengguna Internet di Indonesia 63 Juta Orang. Retrieved 20-03-2019, from Kominfo

https://kominfo.go.id/index.php/content/detail/3415/Kom info+\%3A+Pengguna+Internet+di+Indonesia+63+Juta+ Orang/0/berita_satker

12. Lee, M. J. (2015). Kebudayaan Konsumsi dan Komoditas, Sebuah Kajian Politik Budaya Konsumen. Bantul: Kreasi Wacana.

13. Raditya, M. H. (2014). Antara Rasa dan Estetika Komodifikasi Nilai Konsumsi Pada Pangan Sebagai Wujud Eksistensi. Kawistra, 4(2), 150. doi: 10.22146/kawistara.5669

14. Ritzer, G., \& Goodman, D. J. (2014). Teori Sosiologi Modern. Jakarta: Penerbit Kencana.

15. Stajcic, N. (2013). Understanding Culture: Food as a Means of Communication. Hemisphere, 01(28), 5-14.

16. Warde, A., \& Martens, L. (2003). Eating Out: Social Differentiation, Consumption and Pleasure. Cambridge: Cambridge University Press.

17. WeAreSocial. (2019). DIGITAL 2019: INDONESIA (Report). Retrieved 18-03-2019, from Datareportal https://datareportal.com/reports/digital-2019-indonesia

18. Widyosiswoyo, H. S. (1991). Ilmu Alamiah Dasar. East Jakarta: Ghalia Indonesia.

\section{AUTHORS PROFILE}

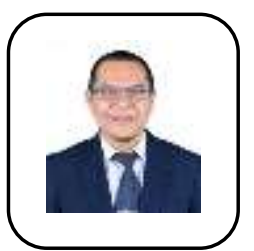

Prof. Dr. Alfitri, M.Si is a Professor of Sociology, Faculty of Social and Political Science, Sriwijaya University. He was born in Lubuk Linggau, South Sumatra, Indonesia, on January 22, 1966. He finished his bachelor's degree in History Science, Faculty of Teacher Training and Education at Sriwijaya University. Then, he continued his master's studies in Department of Sociology, Padjadjaran University and finished in 1995. In 2010, he finished his doctoral's studies in Department of Sociology, Padjadjaran University and became a professor in 2015. Prof. Dr. Alfitri, M.Si is active in research especially in the areas of Community Development and Social Conflict. As a researcher, he also served as Head 
of the Socio-Cultural Research Center at Sriwijaya University in 2000-2004 and as a member of the Regional Research Council of South Sumatra Province in 2001-2005. Until now, he is active in the field of scientific writing by publishing writings in several nationally accredited journals and reputable international journals. He also has written books, namely Sociology and Politics (Unsri Press), Oil and Gas Community Development Companies (Unpad Press), Community Development: Theory and Applications (Yogyakarta Student Library Publishers), and Marginals Community Development (Unsri Press)

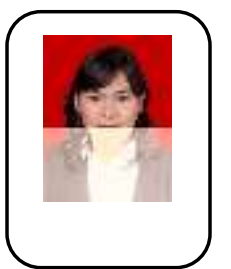

Farisha Sestri Musdalifah, S.Sos., M.Si is a lecturer at the Department of Communication, Faculty of Social and Political Science, Sriwijaya University. She was born in Palembang, South Sumatra, Indonesia, on September 5, 1993. She finished her bachelor's degree in Sociology from Universitas Indonesia in 2016, then continued her master's studies at the Department of Communication Science at Universitas Indonesia. She finished her master's degree in 2018. As a new lecturer, she began actively pursuing research related to lifestyle phenomenon and media studies in the field of Communication Science. 